\title{
Profile Characteristics of Respondents about Transplanting Method of Pigeon Pea Cultivation Practices in Kalaburagi District of Karnataka, India
}

\author{
Ashok Kumar Melkeri* and Syed H. Mazhar \\ Department of Agricultural Extension Education, College of Agriculture, SHIATS, \\ Allahabad-211007, India \\ *Corresponding author
}

\section{A B S T R A C T}

\begin{tabular}{|l|}
\hline K e y w o r d s \\
$\begin{array}{l}\text { Profile characteristics, } \\
\text { Transplanting, Pigeon } \\
\text { pea, Independent } \\
\text { variables }\end{array}$ \\
\hline Article Info \\
\hline $\begin{array}{l}\text { Accepted: } \\
\text { 24 February } 2018 \\
\text { Available Online: } \\
\text { 10 March 2018 }\end{array}$ \\
\hline
\end{tabular}

\section{Introduction}

Development of India cannot be conceived without the development of villages, where agriculture is the main stay of the people. Indian agriculture is not a business, but a way of life. Agriculture is the main source of livelihood of more than 75 per cent of the population and contributes 50 per cent of the national income. Therefore, the development of agriculture has been given priority in the national planning after independence. Indian agriculture consists of different food crops, horticultural crops, ornamental crops and so on are cultivated in different seasons and in
The profile characteristics study was conducted in Kalaburagi district of North eastern Karnataka, during the year 2014-15. The total sample of 120 was derived from three each taluks of a district using random sampling method. Pre-tested interview schedule was used or collection of the information. The independent variables viz., age, education, farming experience, land holding, annual income, risk orientation, scientific orientation, extension participation, mass media utilization and sources of information were studied through a of transplanting method of pigeon pea cultivation revealed that majority of respondents were middle age $(60.83 \%)$, educated up to high school $(37.50 \%)$, medium farming experience $(40.00 \%)$, medium land holdings $(55.83 \%)$, medium income $(48.33 \%)$ and low innovativeness $(44.17 \%)$, medium risk orientation $(55.83 \%)$, medium scientific orientation $(50.83 \%)$ medium extension participation $(48.33 \%)$, maximum number of them used to seek information from mass media and medium level of sources of information (44.17\%). 
according to the recommendations of Indian Council of Medical Research. Pigeon pea [Cajanus cajan (L) Mill sp.] is the second most important pulse crop of India after chickpea. It is cultivated in a multitude of production systems for a diversity of uses grain as dhal, green seed as vegetable and stalk as fuel wood. It is an important pulse crop in the country as well as in the state. It is mainly grown in almost all the states and larger portion of the area is in the states of Maharashtra, Uttar Pradesh, Madhya Pradesh, Karnataka and Gujarat.

In India, pigeon pea is grown in an area of 4.42 million hectares with a production of 2.89 million tonnes and productivity of $655 \mathrm{~kg}$ ha $^{-1}$ (Anon., 2013). India occupies 90 per cent of world pigeon pea area and accounts for 80 per cent of world production of pigeon pea. In India pigeon pea is mainly grown in Maharashtra, Madhya Pradesh, Rajasthan, Uttar Pradesh, Andhra Pradesh and Karnataka. Maharashtra is the leading producer of pigeon pea followed by Madhya Pradesh. The total production of pigeon pea in India 3170.00 thousand tonnes and Share in total Production is $(16.02 \%)$. In Karnataka pigeon pea is largely grown in northern parts, especially in Kalaburagi district. Kalaburagi district is called as pulse bowl of Karnataka and pigeon pea is one of the most important pulse crop grown in this region. It occupies over an area of $3,40,119$ hectare with the production of $2,50,736$ tonnes $(53.68 \%)$ of state pigeon pea production during the year 2014-15.

Recent technological intervention of transplanting method of pigeon pea cultivation is one of the alternate agronomic practices to overcome late sowing and related lower yields of pigeon pea. In addition to advantages of low pest and disease occurrence and higher marginal returns. This technique involves rising of seedlings in polythene bags in the nursery for one month and transplanting the seedlings with the onset of monsoon after the soil profile is uniformly wet. Now it is cultivated mainly in Kalaburagi district in the days to come it may occupy larger pigeon pea cultivated area in the state especially in northern parts of Karnataka. It is one of the recently adopted techniques in the study region and gaining importance in pigeon pea farming community. Hence, the present study is proposed to know profile characteristics level of respondents in transplanting method of pigeon pea cultivation practices.

\section{Materials and Methods}

The research study was conducted in Kalaburagi district of Karnataka state during the year 2014-15. Kalaburagi district was purposively selected for the study because the district is considered as pulse bowl of Karnataka state where in pulses like Black gram, Green gram, Red gram and Bengal gram are grown in 1,95,407 ha area. Among these pulses, the share of pigeon pea is 67,000 ha area. Transplanting method of pigeon pea cultivation is cultivated in Kalaburagi district. Kalaburagi district comprises of seven taluks namely, Afzalpur, Aland, Chincholi, Chittapura, Kalaburagi, Jewargi and Sedam. Out of seven taluks, three taluks namely, Afzalpura, Chittapur and Kalaburagi were purposively selected, because highest area of transplanting was done in these taluks. The list of transplanting pigeon pea farmers were taken from department of Agriculture. A list of villages was prepared for the selected taluks and from the list four villages in each taluk were randomly selected. From each village, 10 respondents were selected constituting a total sample of 120 respondents. Based on the objectives of study, an interview schedule was prepared. The information was elucidated from respondents with the help of structured scheduled. The information was collected by personally interviewing respondents using structured interview schedule. 


\section{Results and Discussion}

Age

Age group plays an important role for participation of respondents in various transplanting activities. It is revealed from Table 1 that majority 60.83 per cent of respondents belonged to middle age category ( 31 to 50 yrs), followed by 21.67 per cent old age group (>51 yrs) and 17.50 per cent young age group (up to 30 yrs) categories.

It is evident from the experience that middle age farmers are enthusiastic and interested to know more and practice on their field with higher work efficiency than old and young age groups. Thus, it can be inferred that the middle aged respondents were in majority $(60.83 \%)$.

\section{Education}

It is observed from Table 2 that 37.50 per cent of the farmers were educated up to high school, followed by graduate 15.83 per cent, middle school 14.17 per cent, college and illiterates 12.50 per cent and primary school 7.50 per cent respectively. In kalaburagi less of the pigeon pea growers were illiterate. This may be due to the availability of high schools at village and taluk places in kalaburagi district.

\section{Farming experience}

The Table 3 indicates that 40.00 per cent of respondents were belonged to medium farming experience category, followed by low experience 33.33 per cent and high experience 26.67 per cent, respectively. The respondents belonged to medium experience because by birth farmers are being dependent on agriculture profession and also inherited culture of farmers from generation to generation to follow the traditional agricultural experience.

\section{Land holding}

As regards land holding of the respondents it is observed from Table 4 that 55.83 per cent of respondents were medium farmers (10.01 to 25.00 acres), followed by 21.67 per cent of respondents were semi medium farmers (5.01 to 10.00 acres), 10.83 per cent of respondents were from small farmers ( 2.51 to 5.00 acres), 5.84 per cent of respondents were marginal farmers (up to 2.50 acres) and 5.00 per cent of respondents were big farmers (>25.00 acres), respectively.

The possible reason that could be attributed to this was these who had agriculture as the main occupation of the family, almost depend on their land for their living. So they always try to possess medium acres of land.

It could also be their ancestor's property. The other reason that could be attributed to this was those who had medium holding, these farmers trying new technology practices in their some portion of land.

\section{Annual income}

It is clear from Table 5 that 48.33 per cent of farmers were belonged to medium income category, followed by high income 27.50 per cent, semi medium income 15.00 per cent. Whereas, least 9.17 per cent number farmers were belonged to low income categories. The strong reason for this could be assured irrigation facility of the respondents. This would enable the farmers to cultivate more than one and diverse crops in a year earning medium income.

\section{Innovativeness}

It is noticed in Table 6 that low innovativeness was exhibited by 44.17 per cent of farmers, while 32.50 per cent of farmers had medium level of innovativeness. 
Table.1 Distribution of respondents according to age

\begin{tabular}{|c|l|c|c|}
\hline SI. No. & \multicolumn{1}{|c|}{ Category } & Frequency & Percentage \\
\hline 1. & Young (up to 30 yrs) & 21 & 17.50 \\
\hline 2. & Middle (31 to 50 yrs) & 73 & 60.83 \\
\hline 3. & Old age (>51 yrs) & 26 & 21.67 \\
\hline & Total & 120 & 100.00 \\
\hline
\end{tabular}

Table.2 Distribution of respondents according to education level

\begin{tabular}{|c|l|c|c|}
\hline Sl. No. & \multicolumn{1}{|c|}{ Education } & Frequency & Percentage \\
\hline 1. & Illiterates & 15 & 12.50 \\
\hline 2. & Primary $\left(1-4^{\text {th }}\right)$ & 9 & 7.5 \\
\hline 3. & Middle $\left(5^{\text {th }}-7^{\text {th }}\right)$ & 17 & 14.17 \\
\hline 4. & High school $\left(8^{\text {th }}-10^{\text {th }}\right)$ & 45 & 37.50 \\
\hline 5. & College $\left(11^{\text {th }}-12^{\text {th }}\right)$ & 15 & 12.50 \\
\hline 6. & Graduate $\left(12^{\text {th }} \&\right.$ above $)$ & 19 & 15.83 \\
\hline & Total & 120 & 100.00 \\
\hline
\end{tabular}

Table.3 Distribution of respondents according to farming experience

\begin{tabular}{|c|l|c|c|}
\hline SI. No. & \multicolumn{1}{|c|}{ Category } & Frequency & Percentage \\
\hline 1. & Low (Mean- 0.425 SD) & 40 & 33.33 \\
\hline 2. & Medium (Mean \pm 0.425 SD) & 48 & 40.00 \\
\hline 3. & High (Mean + 0.425SD) & 32 & 26.67 \\
\hline & Total & 120 & 100.00 \\
\hline & \multicolumn{2}{|c|}{ Mean } & \multicolumn{3}{|c|}{17.63} \\
\hline
\end{tabular}

Table.4 Distribution of respondents according to land holding

\begin{tabular}{|c|l|c|c|}
\hline Sl. No. & \multicolumn{1}{|c|}{ Land Holding } & Frequency & Percentage \\
\hline 1. & Marginal Farmers (up to 2.5 acres) & 7 & 5.84 \\
\hline 2. & Small Farmers (2.51 to 5.00 acres) & 13 & 10.83 \\
\hline 3. & Semi Medium Farmers (5.01 to 10.00 acres) & 26 & 21.67 \\
\hline 4. & Medium Farmers (10.01 to 25.00 acres) & 67 & 55.83 \\
\hline 5. & Big Farmers (>25.00 acres) & 6 & 5.00 \\
\hline & Total & 120 & 100.00 \\
\hline
\end{tabular}


Table.5 Distribution of respondents according to annual income

\begin{tabular}{|c|l|c|c|}
\hline Sl. No. & \multicolumn{1}{|c|}{ Category } & Frequency & Percentage \\
\hline 1. & Low income (up to 17000) & 11 & 9.17 \\
\hline 2. & Semi medium Income $(17001-34000)$ & 18 & 15.00 \\
\hline 3. & Medium income (34001-51000) & 58 & 48.33 \\
\hline 4. & High income (>51000) & 33 & 27.50 \\
\hline & Total & 120 & 100.00 \\
\hline
\end{tabular}

Table.6 Distribution of respondents according to innovativeness

\begin{tabular}{|c|l|c|c|}
\hline Sl. No. & Category & Frequency & Percentage \\
\hline 1. & Low (Mean- 0.425SD) & 53 & 44.17 \\
\hline 2. & Medium (Mean \pm 0.425SD) & 39 & 32.50 \\
\hline 3. & High (Mean + 0.425SD) & 28 & 23.33 \\
\hline & Total & 120 & 100.00 \\
\hline & Mean & \multicolumn{2}{|c|}{9.76} \\
\hline
\end{tabular}

Table.7 Distribution of respondents according to risk orientation

\begin{tabular}{|c|l|c|c|}
\hline SI. No. & Category & Frequency & Percentage \\
\hline 1. & Low (Mean- $0.425 \mathrm{SD})$ & 30 & 25.00 \\
\hline 2. & Medium (Mean \pm 0.425SD) & 67 & 55.83 \\
\hline 3. & High (Mean + 0.425SD) & 23 & 19.17 \\
\hline & Total & 120 & 100.00 \\
\hline & Mean & \multicolumn{2}{|c|}{3.75} \\
\hline
\end{tabular}

Table.8 Distribution of respondents according to scientific orientation

\begin{tabular}{|c|l|c|c|}
\hline Sl. No. & \multicolumn{1}{|c|}{ Category } & Frequency & Percentage \\
\hline 1. & Low (Mean- 0.425SD) & 32 & 26.67 \\
\hline 2. & Medium (Mean \pm 0.425SD) & 61 & 50.83 \\
\hline 3. & High (Mean + 0.425SD) & 27 & 22.50 \\
\hline & Total & 120 & 100.00 \\
\hline & Mean & \multicolumn{2}{|c|}{5.62} \\
\hline
\end{tabular}


Table.9 Distribution of respondents according to extension participation

\begin{tabular}{|c|c|c|c|}
\hline Sl. No. & Category & Frequency & Percentage \\
\hline 1. & Low (Mean- $0.425 \mathrm{SD})$ & 35 & 29.17 \\
\hline 2. & Medium (Mean $\pm 0.425 \mathrm{SD})$ & 58 & 48.33 \\
\hline 3. & High (Mean $+0.425 \mathrm{SD})$ & 27 & 22.50 \\
\hline & Total & 120 & 100.00 \\
\hline & Mean & \multicolumn{2}{|c|}{8.37} \\
\hline
\end{tabular}

Table.10 Distribution of respondents according to mass media utilization

\begin{tabular}{|c|c|c|c|c|c|c|c|c|}
\hline \multirow[t]{3}{*}{ Mass Media } & \multirow{2}{*}{\multicolumn{2}{|c|}{$\begin{array}{c}\text { Possessed/Subs } \\
\text { cribed }\end{array}$}} & \multicolumn{6}{|c|}{ Extent of participation } \\
\hline & & & \multicolumn{2}{|c|}{ Regular } & \multicolumn{2}{|c|}{ Occasional } & \multicolumn{2}{|c|}{ Never } \\
\hline & $\mathbf{F}$ & $\%$ & $\mathbf{F}$ & $\%$ & $\mathbf{F}$ & $\%$ & $\mathbf{F}$ & $\%$ \\
\hline 1.Radio & 12 & 10.00 & & & & & & \\
\hline a) Agriculture & & & 7 & 5.83 & 5 & 4.17 & 108 & 90.00 \\
\hline b) General & & & 7 & 5.83 & 4 & 3.33 & 109 & 90.84 \\
\hline 2.Television & 105 & 87.50 & & & & & & \\
\hline a) Agriculture & & & 59 & 49.17 & 34 & 28.33 & 27 & 22.50 \\
\hline b) General & & & 27 & 22.50 & 51 & 42.50 & 42 & 35.00 \\
\hline 3. Newspaper & 40 & 33.33 & & & & & & \\
\hline a) Agriculture & & & 13 & 10.83 & 25 & 20.83 & 82 & 68.33 \\
\hline b) General & & & 14 & 11.67 & 22 & 18.33 & 84 & 70.00 \\
\hline 4.Farm magazine & 21 & 17.50 & & & & & & \\
\hline a) Agriculture & & & 11 & 9.17 & 8 & 6.67 & 101 & 84.17 \\
\hline b) General & & & 4 & 3.33 & 12 & 10.00 & 104 & 86.67 \\
\hline
\end{tabular}

Table.11 Distribution of respondents according to sources of information

\begin{tabular}{|c|c|c|c|}
\hline Sl. No. & Category & Frequency & Percentage \\
\hline 1. & Low $($ Mean- 0.425 SD) & 34 & 28.33 \\
\hline 2. & Medium $($ Mean $\pm 0.425 S D)$ & 53 & 44.17 \\
\hline 3. & High $($ Mean +0.425 SD) & 33 & 27.50 \\
\hline & Total & 120 & 100.00 \\
\hline & Mean & \multicolumn{2}{|c|}{7.96} \\
\hline
\end{tabular}


However, high innovativeness was noticed in 23.33 per cent of farmers. In present study majority of the transplanting farmers were low to medium degree of innovativeness. The reason might be the farmers had low education level income and risk bearing ability compared to other farmers.

\section{Risk orientation}

It is observed in Table 7 that 55.83 per cent of farmers were belonged to medium risk orientation category, followed by 25.00 per cent of farmers had low risk orientation, While, 19.17 per cent of farmers were belonged to high level of risk orientation category. The individuals with more farming experience, better land holding, and better income had medium risk orientation. This is evident from the results that because contact with extension personnel by the respondents which might have increased the perception and confidence of the respondents about new technologies and to gain more income by taking risk all these factors might have inferred the respondents to be in medium risk orientation.

\section{Scientific orientation}

The analysis of the results presented in Table 8 revealed that 50.83 per cent of farmers were belonged to medium scientific orientation, followed by 26.67 per cent of farmers were belonged to low scientific orientation, whereas by 22.50 per cent of farmers were belonged to high scientific orientation category.

It is the logical thinking, foresight and rationality which help the individual to understand the object. It might be due to this reason that those who had medium scientific orientation had medium knowledge about cultivation practices of transplanting method of pigeon pea cultivation.

\section{Extension participation}

The results presented in Table 9 revealed that 48.33 per cent of farmers were belonged to medium extension participation, followed by 29.17 per cent of farmers were belonged to low extension participation, whereas, 22.50 per cent of farmers were belonged to high extension participation category. The probable reason for above finding might be due to their interest in extension activities, which directly helps them to get the information on relevant innovations, technologies and skills which help them to seek information from extension experts, subject matter specialists, scientist etc. from the Krishi Vigyan Kendra (KVK).

\section{Mass media utilization}

Radio was possessed by 10.00 per cent of the respondents of which, 5.83 and 5.83 per cent of them regularly listen to; while 4.17 and 3.33 per cent of respondents occasionally listened to agricultural and general programmes, respectively.

Television was possessed by 87.50 per cent of the respondents. In which, 49.17 and 22.50 per cent of them regularly viewed; while 28.33 and 42.50 per cent of respondents occasionally viewed to agricultural and general programmes, respectively. In case of newspaper 33.33 per cent of the respondents were subscribes of whom 10.83 and 11.67 per cent of respondents regularly readers; while 20.83 and 18.33 per cent of respondents occasionally reader of agricultural and general news, respectively. In case of farm magazine 17.50 per cent of the respondents were subscribed of whom 9.17 and 3.33 per cent of the respondents were regularly readers; while 6.67 and 10.00 per cent of respondents occasionally readers of agricultural and general programmes, respectively. Thus it can be inferred that television, newspaper were 
main source for getting information and recreation purpose (Table 10).

\section{Sources of information}

It is clear from the Table 11 that 44.17 per cent of farmers were belonged to medium sources of information, followed by 28.33 per cent of farmers were belonged to low sources of information, Whereas, 27.50 per cent of farmers were belonged to high sources of information category. Thus, it can be concluded that most of the transplanting pigeon pea growers were in medium category of sources of information followed by low and high.

The profile characteristics of transplanting method of pigeon pea growers showed that majority of the farmers belonged to middle age group, educated up to high school level, medium farming experience, medium land holdings, medium income, low innovativeness, medium risk orientation, medium scientific orientation, medium extension participation, maximum number them used to seek information from mass media through television and medium level of sources of information. There is a improvement in the profile characteristics of transplanting pigeon pea growers with regard to modern channel, like internet and website is very meagre, since this is an era of liberalization, globalization (under the context of WTO and GATT) there is a need to create awareness among the farmers to their survival. The policy makers and administrators should take care to design awareness programmes regarding internet and agriculture based websites and making easy accessibility of these sources at village level to make new transplanting pigeon pea technology in this era.

\section{References}

Anonymous, 2013 All India area, production and yield of total pulses 2012-13. Ministry of Agriculture, GOI. pp 36-41.

Hanumanaikar, R. H., Jadhav, S. N. and Ashalata, K. V., 2009. Knowledge level and socio-economic profile of sugarcane growers in Karnataka State. Agric. Update, 4 (1\&2): 8-12.

Jadhav, K. K. and Aski, S.G., 2014, Knowledge level of farmers about improved red gram production technologies. Agriculture Update, 9(3): 337-341.

Nirmala D, M. and Manoharan, M., 1999, Contributing characters of Guava cultivators. J. Ext. Edu., 10(2): 24312433.

Palaniswamy, A. and Sriram, N., 2001, Modernization characteristics of sugarcane growers. J. Extn. Educ., 11(4): 2906-2915.

Patel, M.M., Sonoria, Y.C., Chatterjee, A., 2003, Communication factors and entrepreneurial behaivour of sugarcane growers. J. Res., Acharya N. G. Ranga Agril. Univ., Hyderabad, 31(3): 62-67

Shashidhara, K.K., 2003, A study on socioeconomic profile of drip irrigation farmers on Shimoga and davanagere district of Karnataka. M.Sc. (Agri.) Thesis, Univ. Agric. Sci., Dharwad.

\section{How to cite this article:}

Ashok Kumar Melkeri and Syed H. Mazhar. 2018. Profile Characteristics of Respondents about Transplanting Method of Pigeon Pea Cultivation Practices in Kalaburagi District of Karnataka, India. Int.J.Curr.Microbiol.App.Sci. 7(03): 2882-2889.

doi: https://doi.org/10.20546/ijcmas.2018.703.333 